\title{
PENINGKATAN AKTIVITAS BELAJAR PKn MATERI PEMERINTAHAN PUSAT \\ PADA KELAS 4 SEMESTER II SDN 1 KAPONGAN KECAMATAN KAPONGAN \\ KABUPATEN SITUBONDO TAHUN PELAJARAN 2017 / 2018 DENGAN \\ PENDEKATAN CONTEKSTUAL TEACHING LEARNING ( CTL )
}

\author{
IRIYANA, S.PD.SD \\ SDN 1 KAPONGAN
}

\begin{abstract}
Abstrak : Pendidikan kewarganegaraan dalam pengertian sebagai citizenship education, secara substantif dan pedagogis didesain untuk mengembangkan warga negara yang cerdas dan baik untuk seluruh jalur dan jenjang pendidikan. Pendidikan Kewarganegaraan (PKn) merupakan program pendidikan berdasarkan nilai-nilai pancasila sebagai wahana untuk mengembangkan dan melestarikan nilai luhur dan moral yang berakar pada budaya bangsa Indonesia yang diharapkan dapat menjadi jati diri yang diwujudkan dalam bentuk perilaku dalam kehidupan sehari-hari peserta didik baik sebagai individu, sebagai anggota masyarakat dan makhluk ciptaan tuhan Yang Maha Esa. hasil observasi awal di SDN 1 Kapongan, terlihat bahwa situasi belajar mengajar masih menggunakan metode lama yakni Ceramah, hal ini menyebabkan pengajaran yang berpusat pada guru sehingga prestasi belajar siswa pada mata pelajaran PKn di SDN 1 Kapongan masih rendah dan menunjukkan nilai yang masih di bawah Standar Ketuntasan Belajar Minimal $(\mathrm{SKBM}=70)$. Sistem pengajaran yang baik seharusnya dapat membantu siswa mengembangkan diri secara optimal serta mampu mencapai tujuan-tujuan belajarnya. Dari hal tersebut perlu dicarikan alternatif lain untuk meningkatkan hasil belajar PKn siswa pada materi peranan globalisasi. Hal ini mengingat pentingnya pengajaran PKn untuk membentuk karakter siswa tingkat Sekolah Dasar, sehingga dipilihlah pendekatan CTL yang diharapkan dapat meningkatkan minat dan motivasi siswa dalam pembelajaran PKn pada materi peranan globalisasi. Selain itu penerapan CTL menekankan keaktifan siswa dalam pembelajaran sehingga merangsang kemampuan berfikir yang diharapkan dapat meningkatkan prestasi belajar siswa pada pembelajaran PKn pada materi peranan globalisasi.Hasil pembelajaran pembelajaran PKn siswa pada siklus I diketahui jumlah nilai rata-rata yang diperoleh adalah 69.75 dari dua puluh siswa, yang mendapat nilai di atas KKM berjumlah sepuluh orang, dan sisanya masih banyak siswa yang mendapatkan nilai rendah. Hal ini berarti bahwa nilai pembelajaran PKn siswa 50 masih di bawah KKM yang ditetapkan, yaitu 70. Pada Pembelajaran PKn siswa pada siklus II diketahui jumlah nilai rata-rata yang diperoleh adalah 77.75 dari dua puluh siswa, yang mendapat nilai di atas KKM berjumlah enam belas orang, sisanya masih mendapatkan nilai di bawah KKM. Hal ini berarti bahwa nilai pembelajaran PKn siswa 80 sudah di atas KKM yang ditetapkan, yaitu 70.
\end{abstract}

Kata kunci : CTL, Globalisasi, dan PKn.

\section{PENDAHULUAN}

\section{A. Latar Belakang Masalah}

Pendidikan kewarganegaraan dalam pengertian sebagai citizenship education, secara substantif dan pedagogis didesain untuk mengembangkan warga negara yang cerdas dan baik untuk seluruh jalur dan jenjang pendidikan. Pendidikan Kewarganegaraan (PKn) merupakan program pendidikan berdasarkan nilai-nilai pancasila sebagai wahana untuk mengembangkan dan melestarikan nilai luhur dan moral yang berakar pada budaya bangsa Indonesia yang diharapkan dapat menjadi jati diri yang diwujudkan dalam bentuk perilaku 
dalam kehidupan sehari-hari peserta didik baik sebagai individu, sebagai anggota masyarakat dan makhluk ciptaan tuhan Yang Maha Esa.

Pendidikan nasional pendidikan kewarganegaraan terbagi dalam lima status. Pertama, sebagai mata pelajaran disekolah. Kedua, sebagai mata kuliah di perguruan tinggi. Ketiga, sebagai salah satu cabang pendidikan disiplin ilmu pengetahuan sosial dalam kerangka program pendidikan guru. Keempat, sebagai program pendidikan politik yang dikemas dalam bentuk penataran pedoman penghayatan dan pengamalan pancasila (penataran P4). Kelima, sebagai kerangka konseptual dalam bentuk pemikiran individual dan kelompok pakar terkait, yang dikembangkan sebagai landasan dan kerangka berfikir mengenai pendidikan kewarganegaraan dalam empat status yang lain.

Berdasarkan hasil observasi awal di SDN 1 Kapongan, terlihat bahwa situasi belajar mengajar masih menggunakan metode lama yakni Ceramah,. Sistem pengajaran yang berpusat pada guru/sekolah memiliki banyak kelemahan, namun sampai sekarang sistem sekolah pada umumnya dirancang dengan pola seperti ini. Selain itu prestasi belajar siswa pada mata pelajaran PKn di SDN 1 Kapongan masih rendah dan menunjukkan nilai yang masih di bawah Standar Ketuntasan Belajar Minimal (SKBM=70). Sistem pengajaran yang baik seharusnya dapat membantu siswa mengembangkan diri secara optimal serta mampu mencapai tujuan-tujuan belajarnya.

Hasil belajar merupakan ukuran kemampuan siswa setelah menjalani proses belajar. Gagne membagi lima kategori hasil belajar yaitu, informasi verbal, keterampilan intelektual, strategi kognitif, sikap, dan keterampilan motoris.Dari latar belakang di atas perlu dicarikan alternatif lain untuk meningkatkan hasil belajar PKn siswa pada materi peranan globalisasi. Hal ini mengingat pentingnya pengajaran PKn untuk membentuk karakter siswa tingkat Sekolah Dasar, sehingga dipilihlah pendekatan CTL yang diharapkan dapat meningkatkan minat dan motivasi siswa dalam pembelajaran PKn pada materi peranan globalisasi. Selain itu penerapan CTL menekankan keaktifan siswa dalam pembelajaran sehingga merangsang kemampuan berfikir yang diharapkan dapat meningkatkan prestasi belajar siswa pada pembelajaran PKn pada materi peranan globalisasi.

Berdasarkan uraian di atas, penulis tertarik untuk mengadakan penelitian dengan judul "Peningkatan Aktivitas Belajar PKn Materi Pemerintah Pusat Pada Kelas 4 Semester II SDN 1 Kapongan Kecamatan Kapongan Kabupaten Situbondo Tahun Pelajaran 2017 / 2018 Dengan Pendekatan Contekstual Teaching Learning (CTL)”.

\section{B. Identifikasi Area dan Fokus Penelitian}

Berdasarkan latar belakang tersebut maka dapat diidentifikasi masalah yang timbul dan dapat diteliti yaitu:

1. Keterlibatan siswa dalam proses pembelajaran masih kurang

2. Kurangnya motivasi dan minat belajar PKn siswa

3. Prestasi belajar siswa pada pembelajaran PKn khususnya materi peranan globalisasi masih sangat rendah

4. Kegiatan pembelajaran yang masih menggunakan pendekatan yang berpusat kepada guru.

5. Kurangnya pengetahuan guru tentang pendekatan pembelajaran yang inovatif. 


\section{Pembatasan Fokus Penelitian}

Agar penelitian ini lebih terarah dan terfokus serta sesuai dengan keterbatasan penulis dalam hal waktu, tenaga, biaya, maka perlu ada pembatasan masalah. Atas dasar pertimbangan tersebut, penelitian ini dibatasi hanya berusaha meningkatkan hasil belajar Pendidikan Kewarganegaraan ( $\mathrm{PKn}$ ) siswa melalui pendekatan Contekstual Teaching Learning (CTL) di kelas IV SDN 1 Kapongan.

\section{Tujuan Penelitian}

Tujuan dari penelitian ini adalah untuk mengetahui penerapan pendekatan Contekstual Teaching Learning (CTL) yang dapat meningkatkan hasil belajar PKn pada materi peranan globalisasi di kelas IV SDN 1 Kapongan.

\section{E. Manfaat Penelitian}

Manfaat hasil penelitian ini adalah sebagai berikut:

1. Secara teoritis

Hasil penelitian ini diharapkan dapat menambah pengetahuan peneliti tentang pendekatan Contekstual Teaching Learning (CTL) dalam pembelajaran PKn khususnya materi peranan globalisasi.

2. Secara praktis

a. Bagi peserta didik

Penelitian ini diharapkan dapat meningkatkan pembelajaran PKn dalam materi peranan globalisasi karena pendekatan CTL mengajak siswa aktif terlibat dalam kegiatan belajar mengajar.

b. Bagi peneliti

Penelitian ini merupakan pengalaman berharga dalam menerapkan pendekatan CTL dalam pembelajaran PKn sehingga dapat memperbaiki kinerja pembelajaran PKn tentang peranan globalisasi.

c. Bagi sekolah

Penelitian ini diharapkan dapat dijadikan bahan dalam pengembangan dan perbaikan kurikulum tentang pendekatan pembelajaran yang novatif.

\section{KAJIAN TEORI}

\section{A. Acuan Teori Area dan Fokus yang Diteliti}

\section{Hakikat Hasil Belajar PKn}

\section{a. Pengertian Hasil Belajar}

Horwart Kingsley dalam Sudjana menjelaskan bahwa "hasil belajar dapat dibedakan dalam tiga komponen yang diantaranya, Keterampilan dan kebiasaan, Pengetahuan dan pengarahan, Sikap dan cita-cita". maka dapat disimpulkan bahwa hasil belajar merupakan ukuran kemampuan siswa memahami dan menguasai materi pelajaran dan pengetahuan serta kemampuan bertindak serta menggunakan pengetahuan tersebut untuk merubah perilaku menjadi lebih dewasa dan mampu memecahkan masalah.

\section{b. Pengertian PKn}

Menurut Azra, pendidikan kewarganegaraan adalah pendidikan yang cakupannya lebih luas dari pendidikan demokrasi dan pendidikan HAM. Sementara itu, Zamroni berpendapat bahwa Pendidikan Kewarganegaraan adalah pendidikan demokrasi yang bertujuan untuk mempersiapkan warga masyarakat berpikir kritis dan bertindak 
demokratis, melalui aktivitas menanamkan kesadaran kepada generasi baru bahwa demokrasi adalah bentuk kehidupan masyarakat yang paling menjamin hak-hak warga masyarakat.

\section{Hakikat pendekatan CTL}

\section{Pengertian Pendekatan Contextual Teaching and Learning (CTL)}

Pendekatan Contextual Teaching Learning dapat diartikan sebagai, konsep belajar yang membantu guru mengaitkan antara materi yang diajarkan dan situasi dunia nyata dengan mendorong siswa untu membuat hubungan antara pengetahuan yang dimilikinya dengan penerapan dalam kehidupan sehari-hari menjadi alternatif strategi belajar yang baru.Komponen-Komponen Pembelajaran CTL.

Ada tujuh komponen pembelajaran CTL yaitu Konstruktivisme, inkuiri, bertanya (questioning), masyarakat belajar (Learning community), pemodelan (modelling), refleksi, dan penilaian autentik.

\section{METODOLOGI PENELITIAN}

\section{A. Tempat dan Waktu Penelitian}

Tempat : SDN 1 Kapongan Kecmatan Kapongan Kabupaten Situbondo, dibantu oleh guru (observer langsung) dan ikut mengamati kegiatan.

Waktu : Semester Genap 2017 / 2018 yaitu bulan April sampai Juli 2018. Planing dilakukan pada bulan April, tahap pelaksanaan dimulai bulan Mei, tahap analisis data dimulai pada bulan Juni, dan penyusunan laporan akan dilaksanakan pada bulan Juli.

\section{B. Metode Penelitian dan Rancangan}

Penelitian tindakan kelas menurut Tim Pelatih Proyek PGSM adalah "suatu bentuk kajian yang bersifat reflektif oleh oelaku tindakan, yang dilakukan untuk meningkatkan kemantapan rasional dari tindakan-tindakan mereka dalam melaksanakan tugas, memperdalam pemahaman terhadap tindakan-tindakan yang dilakukannya itu, serta memperbaiki kondisi dimana praktek-praktek pembelajaran tersebut dilakukan”.

Pada penelitian ini peneliti menggunakan 2 siklus. Dalam pelaksanaannya siklus dapat dihentikan apabila 70\% telah tercapai tujuan atau kompetensi pembelajaran dengan nilai KKM 70 yang sesuai dengan SKBM SDN 1 Kapongan Kecamatan Kapongan Kabupaten Situbondo. Penelitian ini harus dilakukan dengan benar sesuai kaidah-kaidah PTK. dalam PTK mempunyai beberapa model tetapi dalam pelaksanaannya secara garis besar terdapat empat tahapan yaitu: perencanaan, pelaksanaan, pengamatan, dan refleksi. Dibawah ini terdapat rancangan tiap siklus, yaitu:

\section{a. Siklus I}

\section{Perencanaan (Planning)}

Dalam perencanaan siklus I, peneliti menetapkan seluruh perencanaan tindakan yang akan dilakukan, dengan langkah-langkah sebagai berikut:

Menyusun RPP dengan materi peranan globalisasi, mempersiapkan sumber dan media pembelajaran, menyiapkan lembar kerja kelompok, serta menyiapkan lembar observasi. Dalam siklus I ini akan diadakan dalam $2 \mathrm{x}$ pertemuan.

\section{Pelaksanaan (Acting)}

Dalam tahap pelaksanaan guru membagi siswa dalam 5 kelompok, yang masing- 
masing terdiri dari 4 orang. Guru memberikan penjelasan singkat tentang materi pembelajaran, mengenalkan media atau alat pembelajaran, menjelaskan tentang pendekatan CTL, siswa mengembangkan pemikiran dan rasa ingin tahu untuk belajar dengan cara mengkonstruksi pengetahuan dan keterampilannya, melakukan kegiatan inkuiri untuk materi peranan globalisasi dengan cara bertanya, menciptakan masyarakat belajar dengan cara kerja kelompok dan memanfaatkan lingkungan yang ada, menghadirkan model, melakukan refleksi, selanjutnya guru dan siswa membuat kesimpulan.

\section{Pengamatan (Observing)}

Mengamati aktivitas belajar siswa dan aktivitas guru dalam memotivasi siswa pada saat kegiatan pembelajaran.

\section{Refleksi (Reflecting)}

Mengevaluasi hasil observasi, menganalisis hasil pembelajaran dan menyusun rencana tindakan berikutnya.

\section{b. Siklus II}

pada tahapan 1. Perencanaan (Planning) dan 2. kedua Pelaksanaan (Action) sama seperti Siklus I, bedanya hanya terletak pada :

\section{Pengamatan (Observing)}

Pengamatan lebih difokuskan untuk mengetahui adanya peningkatan dalam pembelajaran dari kegiatan siklus I.

\section{Refleksi (Reflecting)}

mengevaluasi serta menganalisis hasil observasi lanjutan, hasil pembelajaran dan menyusun rencana tindakan berikutnya.

\section{Subjek/Partisipan dalam Penelitian}

Dalam PTK ini, yang menjadi subjek penelitian adalah siswa kelas IV SDN 1 Kapongan Kecamatan Kapongan Kabupaten Situbondo semester II tahun ajaran 2017/2018 yang terdiri dari 20 siswa dengan komposisi 8 orang siswa laki-laki dan 12 orang siswa perempuan.

\section{Peran dan Posisi Peneliti dalam Penelitian}

Peneliti bertindak sebagai guru PKn yang memberikan tindakan dalam pembelajaran, peneliti bekerjasama dengan observer dalam pelaksanaan pembelajaran yaitu guru kelas IV.

\section{E. Tahap Intervensi Tindakan}

1. Rencana Tindakan (Planning)

2. Pelaksanaan Tindakan (Acting)

3. Pengamatan (Observing)

4. Refleksi (Reflecting)

\section{F. Data dan Sumber Data}

Data tes objektif berupa penilaian atas penguasaan konsep siswa alam bentuk tes tertulis dan tes kinerja secara berkelompk, sedangkan tes tertulis dilakukan pada akhir tindakan. Hasil tes tulis siswa akan diolah menjadi nilai akhir sebagai tolak ukur keberhasilan atau kegagalan dalam pencapaian tujuan. Data hasil pengamatan, adalah untuk mengetahui peningkatan pembelajaran PKn dilakukan observasi pada masingmasing siswa baik kegiatan observasi langsung maupun tak langsung yang dinilai oleh peneliti. Untuk mengetahui tanggapan atau respon siswa terhadap peningkatan pembelajaran 
PKn dengan pendekatan CTl, serta untuk mengetahui espon siswa terhadap observer (Sangat Kurang, Kurang, Cukup Baik, Baik)

\section{G. Instrumen Pengumpulan Data}

\section{Instrumen Tes}

Menurut Ngalim Purwanto tes hasil belajar adalah "tes yang dipergunakan untuk menilai hasil-hasil pelajaran yang telah diberikan oleh guru kepada muridmuridnya, dalam jangka waktu tertentu". Berdasarkan beberapa penjelasan diatas, dapat disimpulkan bahwa tes adalah alat atau prosedur untuk mengukur keberhasilan proses belajar mengajar dan mengukur tingkat perkembangan dan kemajuan peserta didik yang memerlukan jawaban benar atau salah. Adapun jenis tes yang digunakan dalam penelitian ini adalah tes tertulis. Tes tertulis ini merupakan postest, diberikan pada saat pembelajaran berlangsung, untuk mengetahui hasil belajar setelah mereka mendapatkan pmbelajaran

\section{Instrumen Non Tes}

\section{a. Pedoman Wawancara}

Wawancara dilakukan oleh peneliti dengan menanyakan beberapa pertanyaan tentang data yang berkenaan dengan aspek permasalahan pembelajaran PKn siswa.

\section{b. Lembar Observasi}

Lembar observasi digunakan untuk mengukur sejauh mana tindakan yang dilakukan peneliti telah mencapai tujuan. Lembar observasi ini berisi aspek-aspek tingkah laku yang terjadi selama proses pembelajaran, baik aktivitas guru maupun aktivitas siswa. Dalam observasi ini peneliti menggunakan skala bertingkat.

\section{c. Catatan Lapangan}

Catatan lapangan merupakan temuan yang diperoleh peneliti pada proses pembelajaran, temuan tersebut dapat berupa aktivitas siswa dan permasalahan yang dihadapi selama pembelajaran berlangsung.

\section{d. Jurnal Siswa}

Pemberian jurnal siswa dilakukan setiap akhir pembelajaran. Laporan dari jurnal siswa akan digunakan sebagai tindakan untuk memperbaiki pada siklus pembelajaran selanjutnya.

\section{e. Dokumentasi}

Dokumen yang digunakan dalam penelitian ini berupa LKS, daftar nilai siswa, dan dokumentasi foto.

\section{Teknik Pengumpulan Data}

Teknik yang digunakan meliputi teknik tes dan nontes, dengan menggunakan beberapa instrument yang telah dijelaskan diatas.

\section{J. Teknik Pemeriksaan Keterpercayaan Studi}

Pada penelitian ini digunakan teknik analisis deskriptif kualitatif, yaitu suatu metode penelitian yang bersifat menggambarkan kenyataan atau fakta sesuai dengan data yang diperoleh dengan tujuan untuk mengetahui hasil belajar yang dicapai siswa, juga untuk memperoleh respon terhadap kegiatan pembelajaran serta aktivitas siswa selama proses pembelajaran.

\section{Untuk menilai hasil belajar}


Gain adalah selisih antara nilai post test dan pre test, gain menunjukkan peningkatan pemahaman atau penguasaan konsep siswa setelah pembelajaran dilakukan guru. Untuk mengetahui selisih nilai tersebut, menggunakan Normalized Gain.

Dengan kategori :

$$
\mathrm{g}=\frac{\text { Skor post test }- \text { Skor pretest }}{\text { Skor ideal }- \text { Skor pretest }}
$$

$$
\begin{array}{ll}
\text { g tinggi } & =\text { nilai }(\mathrm{g})>0,70 \\
\text { g sedang } & =0,70>(\mathrm{g})>0,3 \\
\text { g rendah } & =\text { nilai }(\mathrm{g})<0,3
\end{array}
$$

\section{Lembar observasi guru dan siswa}

Untuk menghitung lembar observasi aktivitas guru dan siswa digunakan rumus sebagai berikut:

a. Aktivitas guru

$$
\text { Jumlah rata-rata keseluruhan }=\frac{\text { Jumlah Skor Yang Didapat Siswa }}{\text { Jumlah Siswa }}
$$

b. Aktivitas siswa

$$
\text { Rata-rata skor }=\frac{\text { Jumlah Skor Yang Didapat Guru }}{\text { Jumlah Pertemuan }}
$$

\section{KKM (Kriteria Ketuntasan Minimal)}

Untuk KKM mata pelajaran PKN di SDN 1 Kapongan Kecamatn Kapongan Kabupaten Situbondo kelas IV adalah 7,0 (tujuh koma nol). Yaitu seorang siswa telah tuntas belajar bila telah mencapai nilai 70 .

\section{DESKRIPSI, ANALISIS DATA, INTERPRETASI HASIL ANALISIS DAN PEMBAHASAN}

\section{A. Deskripsi Data Hasil Pengamatan/Hasil Interpensi Tindakan}

1. Deskripsi Kondisi Awal (Pra Siklus)

a. Hasil Wawancara dengan Guru dan Siswa

Senin, 7 April 2018. Peneliti melakukan wawancara dengan Bapak Moch. Rizal (guru kelas IV) dan beberapa siswa kelas IV sebagai narasumbernpada jam istirahat. Menurut guru, minat siswa terhadap pembelajaran PKn masih sangat rendah sehingga kurangnya keaktifan siswa dalam pembelajaran, dan kurangnya usaha guru dalam menerapkan pendekatan pembelajaran yang inovatif sehingga berakibat rendahnya hasil belajar siswa pada pembelajaran PKn khususnya pada materi peranan globalisasi.

Pendapat tersebut juga didukung oleh hasil wawancara dengan beberapa siswa kelas IV mengenai minat mereka terhadap pelajaran PKn. Pada umumnya mereka menyatakan kurang suka mengikuti pembelajaran PKn di kelas, mereka merasa bosan dengan pembelajaran yang disampaikan oleh guru karena kurang inovatif dan metode yang kurang melibatkan siswa dalam pembelajaran, sehingga mengakibatkan hasil belajar siswa yang berada di bawah KKM.

b. Pengamatan Proses Pembelajaran di Kelas

a. Permintaan izin penelitian kepada kepala sekolah untuk meneliti kelas SDN 1 Kapongan.

b. Penentuan tanggal penelitian yang akan dilaksanakan pada tanggal 7-14 Mei 2018 
untuk pelaksanaan siklus I, selanjutnya siklus II dilaksanakan pada tanggal $21 \mathrm{Mei}-4$ Juni 2018.

c. Penentuan alokasi waktu yang disetujui oleh kepala sekolah dan wali kelas IV. Waktu yang telah ditentukan adalah pada jam ke-5 dan ke-6 sesuai dengan jadwal yang ada di sekolah dengan alokasi waktu pada tiap pertemuan adalah 2 x 35 menit atau 70 menit.

d. Pemaparan RPP tentang materi PKn, pemilihan metode yang akan diterapkan dan model evaluasi yang akan digunakan dalam pembelajaran selama tindakan.

e. Standar Kelulusan Belajar Minimal (SKBM) PKn kelas IV SDN 1 Kapongan adalah 70 .

Kemudian peneliti dan wali kelas IV berdiskusi dan membatasi fokus penelitian hanya pada Materi Pemerintahan Pusat pada siswa kelas IV dengan menggunakan pendekatan CTL dengan jumlah peserta didik dua puluh orang yang terdiri dari 8 orang lakilaki dan 12 orang perempuan.

\section{Deskripsi Pelaksanaan Tindakan Siklus I}

Tindakan pada siklus I dilaksanakan dua kali pertemuan. Setiap pertemuan terdiri dari 2 jam pelajaran ( 2 x 35 menit). Siklus I dilaksanakan pada hari Rabu, 7 dan 14 Mei 2018. Tahapan-tahapan pada siklus I adalah sebagai berikut:

\section{a. Perencanaan tindakan}

1) Menyusun Rencana Pelaksanaan Pembelajaran (RPP)

RPP disusun berdasarkan Kurikulum Tingkat Satuan Pendidikan (KTSP) kelas IV semester II tahun 2013 materi peranan globalisasi. Rencana Pelaksanaan Pembelajaran pada siklus I dirancang dengan 2 kali pertemuan. Alokasi setiap pertemuan adalah 2x35 menit, total alokasi waktu 4x35 menit. Rancangan pelaksanaan pembelajaran yang dibuat mencakup penentuan identitas RPP, standar kompetensi, kompetensi dasar, indikator, tujuan pembelajaran, materi pembelajaran, metode pembelajaran, langkah-langkah pembelajaran, sumber dan media pembelajaran, dan teknik penilaian.

2) Mempersiapkan fasilitas dan sarana pendukung

Fasilitas yang perlu dipersiapkan dalam pembelajaran adalah:

a) Ruang kelas, ruang kelas yang digunakan adalah kelas IV yang biasa digunakan sehari-hari. Ketika pembelajaran berlangsung, kursi diatur sedemikian rupa, sehingga mereka dapat melaksanakan proses pembelajaran dengan kondusif.

b) Materi pembelajaran, materi pada pertemuan pertama dan kedua mempelajari tentang peranan globalisasi. Materi tersebut dilaksanakan dengan Pendekatan CTL

c) Mempersiapkan media pembelajaran, media pembelajaran yang digunakan adalah laptop dan HP serta gambar- gambar sebagai model dalam pembelajaran PKn pada materi peranan globalisasi.

3) Menyiapkan lembar observasi yang menggunakan pendekatan CTL

4) Menyiapkan instrumen penilaian

b. Pelaksanaan Tindakan

1) Pertemuan Pertama

Tindakan siklus I pada pertemuan pertama dilaksanakan pada hari Rabu, 7 Mei 2018 pada jam ke-5 dan ke-6 dengan alokasi waktu 70 menit ( 2 x 35 menit). Pada kegiatan awal waktu yang digunakan adalah 10 menit. Guru memulai kegiatan belajar mengajar 
dengan membaca doa sebagai pembuka pembelajaran, mengkondisikan siswa agar siap mengikuti pembelajaran hari ini, selanjutnya guru memberika apersepsi yaitu menanyakan kembali materi sebelumnya. Guru juga memberikan motivasi dengan menghubungkan pembelajaran hari ini dengan kehidupan sehari-hari yang pernah dialami oleh siswa. Pada saat tahap eksplorasi di kegiatan inti guru bertanya jawab dengan siswa tentang Globalisasi, dan memberikan kesempatan kepada siswa untuk bertanya tentang hal-hal yang belum dimengerti.

Pada tahap elaborasi guru meminta siswa membuat kelompok yang terdiri dari empat orang. Guru membagikan pada masing-masing kelompok LKS yang akan digunakan dalam pembelajaran dengan menggunakan laptop dan HP sebagai model . Melalui diskusi kelompok guru meminta siswa untuk membuat pertanyaan sebanyak-banyaknya dengan cara memanipulasi model yang telah disediakan setelah diskusi selesai, masing-masing kelompok diminta untuk mempresentasikan hasil kerjanya di depan kelas.

Pada kegiatan penutup guru dan siswa menyimpulkan serta mengingatkan kepada siswa yang belum mempresentasikan hasil kerjanya untuk dilanjutkan pada pertemuan yang akan datang, dan pembelajaran diakhiri dengan doa penutup.

\section{2) Pertemuan Kedua}

Perencanaan pada pertemuan kedua dilaksanakan pada hari Rabu, 14 Mei 2013 pada jam ke-5 dan ke-6, pertemuan ini adalah kelanjutan dari pertemuan pertama, tahap pertama dan kedua pada kegiatan kedua ini sama seperti apa yang dilakuan dikegiatan pertama. Bedanya terletak pada kegiatan penutup guru dan siswa menyimpulkan serta mengingatkan kepada siswa yang belum mempresentasikan hasil kerjanya untuk dilanjutkan pada pertemuan yang akan datang, dan pembelajaran diakhiri dengan doa penutup. Sebagai refleksi guru mengadakan postest sebagai penilaian pada pembelajaran PKn. Hasil nilai postest siswa pada siklus I dapat dilihat pada tabel berikut ini.

Terlihat adanya peningkatan siswa yang mendapat nilai di atas KKM sebanyak sepuluh orang. Berdasarkan hasil tersebut siswa yang memperoleh nilai di atas KKM yang ditentukan yaitu 70 baru mencapai 50 sehingga peneliti akan mengadakan tindakan selanjutnya yaitu siklus II.

\section{c. Pengamatan (Observasi)}

Pengamatan dilaksanakan dengan mengamati aktivitas siswa selama pembelajaran berlangsung dan aktivitas guru. Pengamatan aktivitas siswa dilakukan oleh observer yaitu guru kelas IV, sedangkan pengamatan aktivitas guru dilakukan oleh siswa dan observer. Berdasarkan pengamatan terhadap tingkah laku siswa selama pembelajaran berlangsung diperoleh data sebagai berikut:

Tabel. 8

Penilaian Aktivitas Guru pada Siklus I

\begin{tabular}{|l|l|c|}
\hline No & \multicolumn{1}{|c|}{ Kategori Pengamatan } & Jumlah Skor \\
\hline 1. & Guru mempersiapkan siswa untuk belajar & 77 \\
\hline 2. & Guru memotivasi siswa & 89 \\
\hline 3. & Guru menyampaikan tujuan pembelajaran & 92 \\
\hline 4. & Guru menjelaskan materi pembelajaran & 76 \\
\hline 5. & Guru mengatur siswa dalam kelompok-kelompok belajar & 81 \\
\hline
\end{tabular}




\begin{tabular}{|l|l|c|}
\hline 6. & $\begin{array}{l}\text { Guru menggunakan media atau alat pendukung pembelajaran PKn } \\
\text { dengan pendekatan CTL }\end{array}$ & 90 \\
\hline 7. & Guru menggunakan teknik yang tepat dalam pembelajaran & 76 \\
\hline 8. & $\begin{array}{l}\text { Guru memberikan tugas sesuai dengan materi pembelajaran yang } \\
\text { disampaikan }\end{array}$ & 84 \\
\hline 9. & Guru mengawasi kelompok secara bergiliran & 80 \\
\hline 10. & $\begin{array}{l}\text { Guru memberikan bantuan kepada kelompok yang mengalami } \\
\text { kesulitandalam tugas kelompok }\end{array}$ & 93 \\
\hline & \multicolumn{1}{|c}{ Jumlah Rata-Rata Skor } & 36,43 \\
\hline
\end{tabular}

Jumlah rata-rata keseluruhan = Jumlah skor yang didapat siswa Jumlah siswa

\section{Dimana skala penilaian rata-rata tiap aspek:}

1. Sangat kurang

2. Kurang

3. Cukup

4. Baik

5. Sangat baik

\section{Skala penilaian jumlah rata-rata:}

10-19= Prestasi kurang baik

20-26= Prestasi kurang

27-33 = Prestasi cukup

34-40 = Prestasi baik

41-50= Prestasi sangat baik

Berdasarkan tabel di atas jumlah rata-rata keseluruhan adalah 36,43 hal itu berarti guru memiliki prestasi yang baik selama pembelajaran berlangsung.

\section{d. Refleksi}

Catatan lapangan pada setiap pertemuan menunjukkan:

1) Masih banyak siswa yang merasa takut dan malu maju ke depan kelas untuk mempresentasikan hasil kerjanya, namun pada pertemuan yang kedua siswa sudah mulai berani untuk maju ke depan dan hanya sedikit siswa yang masih merasa takut dan malu.

2) Pada pertemuan pertama siswa masih belum terbiasa dengan metode yang diterapkan oleh guru, namun pada pertemuan kedua siswa sudah mulai antusias dan merasa senang dalam mengikuti pembelajaran.

3) Masih banyak siswa yang belum bisa membuat pertanyaan dengan memanipulasi model yang disediakan.

4) Hasil belajar siswa belum mencapai KKM yang diharapkan yaitu 70. Berdasarkan temuan-temuan tersebut maka peneliti memutuskan untuk mengadakan tindakan selanjutnya yaitu pada siklus II.

\section{Deskripsi Pelaksanaan Tindakan Siklus II}

Tindakan pada siklus II dilaksanakan dua kali pertemuan. Setiap pertemuan terdiri dari 2 jam pelajaran (2 x 35 menit). Siklus II dilaksanakan pada hari Rabu, 21 Mei 2013 (pertemuan pertama) dan hari Rabu, 4 Juni 2013 (pertemuan kedua). Tahapan-tahapan pada siklus II adalah sebagai berikut:

\section{a. Perencanaan tindakan}

Tahapan-tahapan dalam perencanaan adalah: 
1) Menyusun Rencana Pelaksanaan Pembelajaran (RPP)

RPP disusun berdasarkan Kurikulum Tingkat Satuan Pendidikan (KTSP) kelas IV semester II tahun 2018 materi peranan globalisasi. Rencana Pelaksanaan Pembelajaran pada siklus I dirancang dengan 2 kali pertemuan. Alokasi setiap pertemuan adalah $2 \times 35$ menit, sehingga dalam satu siklus terdapat alokasi waktu 4x35 menit. Rancangan pelaksanaan pembelajaran yang dibuat sama mencakupnya pada siklus I, Mulai dari penentuan identitas RPP, standar kompetensi, sampi dengan teknik penilaian.

2) Mempersiapkan fasilitas dan sarana pendukung :

a) Ruang kelas, ruang kelas yang digunakan adalah kelas IV yang biasa digunakan sehari-hari. Ketika pembelajaran berlangsung, kursi diatur sedemikian rupa, sehingga mereka dapat melaksanakan proses pembelajaran dengan kondusif.

b) Materi pembelajaran, materi pada pertemuan pertama dan kedua mempelajari tentang peranan globalisasi. Materi tersebut dilaksanakan dengan Pendekatan CTL.

c) Mempersiapkan media pembelajaran, media pembelajaran yang digunakan adalah HP dan gambar-gambar sebagi model dalam pembelajaran PKn pada materi Peranan Globalisasi

3) Menyiapkan lembar observasi

4) Menyiapkan instrumen penilaian

b. Pelaksanaan tindakan

Pelaksanaan siklus II dilaksanakan dalam dua kali pertemuan, pada hari Rabu, 21 Mei 2018 dan Rabu, 4 Juni 2018. Pelaksanaan tindakan tersebut dilaksanakan di ruang kelas IV SDN 1 Kapongan Kecamatan Kapongan Kabupaten Situbondo.

\section{Deskripsi pada pertemuan pertama adalah sebagai berikut:}

\section{1) Pertemuan Pertama}

Tindakan siklus II pada pertemuan pertama dilaksanakan pada hari Rabu, 21 Mei 2018 pada jam ke-5 dan ke-6 dengan alokasi waktu 70 menit ( 2 x 35 menit). Pada tahapan pertama, kedua, dan ketiga isi kegiatannya sama halnya dengan tidakan yang dilakukan pada saat siklus I.

\section{2) Pertemuan Kedua}

Perencanaan pada pertemuan kedua dilaksanakan pada hari Rabu, 4 Juni 2018 pada jam ke-5 dan ke-6, pertemuan ini adalah kelanjutan dari pertemuan pertama. Tahap pertahap yang dilakukan dipertemuan kedua sama persis dengan yang dilaksankan pada pertemuan pertama, bedanya hanya terletak pada kegiatan penutup guru dan siswa menyimpulkan serta mengingatkan kepada siswa yang belum mempresentasikan hasil kerjanya untuk dilanjutkan pada pertemuan yang akan datang, dan pembelajaran diakhiri dengan doa penutup. Sebagai refleksi guru mengadakan postest sebagai penialain pada pembelajaran PKn.

Dari hasil postest terlihat adanya peningkatan siswa yang mendapat nilai di atas KKM sebanyak enam belas orang yaitu. Berdasarkan hasil tersebut siswa yang memperoleh nilai di atas KKM sudah mencapai 80 sehingga peneliti akan menyatakan penelitian telah selesai hanya sampai pada siklus II.

\section{c. Pengamatan (Observasi)}

Berdasarkan pengamatan terhadap tingkah laku siswa selama pembelajaran 
berlangsung diperoleh data sebagai berikut:

Tabel. 8

Penilaian Aktivitas Guru pada Siklus II

\begin{tabular}{|l|l|c|}
\hline No & \multicolumn{1}{|c|}{ Kategori Pengamatan } & Jumlah Skor \\
\hline 1. & Guru mempersiapkan siswa untuk belajar & 79 \\
\hline 2. & Guru memotivasi siswa & 89 \\
\hline 3. & Guru menyampaikan tujuan pembelajaran & 86 \\
\hline 4. & Guru menjelaskan materi pembelajaran & 105 \\
\hline 5. & Guru mengatur siswa dalam kelompok-kelompok belajar & 99 \\
\hline 6. & $\begin{array}{l}\text { Guru menggunakan media atau alat pendukung pembelajaran PKn } \\
\text { dengan pendekatan CTL }\end{array}$ & 88 \\
\hline 7. & Guru menggunakan teknik yang tepat dalam pembelajaran & 90 \\
\hline 8. & $\begin{array}{l}\text { Guru memberikan tugas sesuai dengan materi pembelajaran yang } \\
\text { disampaikan }\end{array}$ & 98 \\
\hline 9. & Guru mengawasi kelompok secara bergiliran & 93 \\
\hline 10. & $\begin{array}{l}\text { Guru memberikan bantuan kepada kelompok yang mengalami } \\
\text { kesulitandalam tugas kelompok }\end{array}$ & 98 \\
\hline & \multicolumn{2}{|c|}{ Jumlah Rata-Rata Skor } \\
\hline
\end{tabular}

Jumlah rata-rata keseluruhan $=$ Jumlah skor yang didapat siswa

Jumlah siswa

Dimana skala penilaian rata-rata tiap aspek:

1. Sangat kurang

2. Kurang

3. Cukup

4. Baik

5. Sangat baik

Skala penilaian jumlah rata-rata:

10-19= Prestasi kurang baik

20-26= Prestasi kurang

27-33= Prestasi cukup

34-40= Prestasi baik

41-50= Prestasi sangat baik

Berdasarkan tabel di atas jumlah rata-rata keseluruhan adalah 37,0 hal itu berarti guru memiliki prestasi yang baik selama belajar mengajar berlangsung.

\section{d. Refleksi}

Tindakan pada siklus II ini dilaksanakan selama $2 \mathrm{x}$ pertemuan menunjukkan hasil yang diharapkan yaitu jika 80 dari siswa telah mencapai nilai di atas KKM yang telah ditetapkan yaitu 70, maka tindakan ini berhasil. Melihat dari analisis data yang diperoleh bahwa tindakan dalam penelitian ini telah lebih dari 70 dan siswa telah mencapai batas kriteria ketuntasan minimal.

\section{Analisis Data}

\section{Hasil Analisis Data}

Pembelajaran PKn siswa pada siklus I diketahui jumlah nilai rata-rata yang diperoleh adalah 69.75 dari dua puluh siswa, yang mendapat nilai di atas KKM berjumlah sepuluh 
orang, dan sisanya masih banyak siswa yang mendapatkan nilai rendah. Hal ini berarti bahwa nilai pembelajaran PKn siswa 50 masih di bawah KKM yang ditetapkan, yaitu 70.

Pembelajaran PKn siswa pada siklus II diketahui jumlah nilai rata-rata yang diperoleh adalah 77.75 dari dua puluh siswa, yang mendapat nilai di atas KKM berjumlah enam belas orang, sisanya masih mendapatkan nilai di bawah KKM. Hal ini berarti bahwa nilai pembelajaran PKn siswa 80 sudah di atas KKM yang ditetapkan, yaitu 70.

\section{Analisis Data Nilai}

Di bawah ini hasil data pembelajaran PKn siswa kelas IV SDN 1 Kapongan dari awal sebelum tindakan sampai siklus II, yaitu:

Tabel. 12

Perbandingan Hasil Pembelajaran PKn Siswa Kelas IV

SDN 1 Kapongan

\begin{tabular}{|c|l|c|c|c|}
\hline No & \multicolumn{1}{|c|}{ Deskripsi } & $\begin{array}{c}\text { Awal sebelum } \\
\text { tindakan }\end{array}$ & Siklus I & Siklus II \\
\hline 2 & Jumlah seluruh nilai & 1261 & 1395 & 1555 \\
\hline 3 & Rata-rata nilai & 63.05 & 69.75 & 77.75 \\
\hline 4 & Persentase skor & 63 & 69.75 & 77.75 \\
\hline
\end{tabular}

\section{Interpretasi Hasil Analisis}

1. Dilihat dari data penilaian terhadap guru bahwa pada siklus I rata-rata skor penilaian 36,43. Sedangkan pada silus II rata-rata skor penilaian 37,0. (Terdapat Peningkatan)

2. Hasil belajar diatas membuktikan bahwa hasil penelitian pembelajaran PKn dengan pendekatan CTL ada perbedaan atau peningkatan yang signifikan.

\section{Pembahasan Tentang Penemuan}

\section{Deskripsi Tingkah Laku Siswa dalam Pembelajaran} Hasil Rata-rata Skor Aktivitas Siswa Kelas IV SDN 1 Kapongan(Tabel.13)

\begin{tabular}{|c|c|c|c|}
\hline \multirow{2}{*}{ No } & \multirow{2}{*}{ Kategori Pengamatan } & \multicolumn{2}{|c|}{ Skor Penilaian } \\
\hline & & Siklus I & Siklus II \\
\hline 1. & $\begin{array}{l}\text { Siswa memberikan respon positif selama pembelajaran } \\
\text { berlangsung }\end{array}$ & 8 & 9 \\
\hline 2. & Siswa Memperhatikan dan menyimak penjelasan guru dengan baik & 7 & 8 \\
\hline 3. & Siswa aktif dalam mengajukan pertanyaan & 8 & 9 \\
\hline 4. & Siswa aktif dalam menjawab pertanyaan yang diajukan guru & 6 & 7 \\
\hline 5. & $\begin{array}{l}\text { Siswa sering memotivasi dan membantu kelompoknya dalam } \\
\text { mengerjakan tugas kelompok }\end{array}$ & 6 & 7 \\
\hline 6. & Siswa mengerjakan tugas kelompoknya dengan serius & 8 & 9 \\
\hline 7. & Siswa memiliki tanggung jawab dan kerjasama dalam kelompok & 8 & 8 \\
\hline 8. & Siswa mengikuti pembelajaran dari awal sampai akhr & 8 & 9 \\
\hline & Jumlah Skor & 59 & 66 \\
\hline & Rata-Rata & 29,5 & 33 \\
\hline
\end{tabular}


Rata-rata Skor = Jumlah Skor yang didaapat Guru

Jumlah Pertemuan

\section{Pertemuan siklus I}

Rata-rata skor $=\underline{59}=29.5$

$$
2
$$

\section{Pertemuan siklus II}

Rata-rata skor $=\frac{66}{2}=33$

Dimana skala penilaian rata-rata tiap aspek:

1. Sangat kurang baik (SKB)

2. Kurang baik $(\mathrm{KB})$

3. Cukup (C)

4. Baik (B)

5. Sangat Baik (SB)

Skala penilaian keseluruhan, 8-15 = prestasi $\mathrm{KB}, 16-21$ = prestasi $\mathrm{K}, 22-27$ = prestasi $\mathrm{C}$, 28$33=$ prestasi $\mathrm{B}, 34-40=$ prestasi $\mathrm{SB}$

\section{Hasil Analisis Catatan Lapangan dan Jurnal Siswa dalam Pembelajaran}

a. Hasil catatan lapangan selama pembelajaran siklus I dan siklus II :

1) Dalam catatan lapangan terlihat aktivitas siswa dengan pendekatan CTL dapat menciptakan suasana pembelajaran yang menyenangkan sehingga siswa berani dan siap maju mempresentasikan hasil diskusi kelompok ke depan kelas dan hal ini dapat membangkitkan motivasi siswa untuk berani berbicara tanpa rasa takut dan malu.

2) Pembelajaran yang dikaitkan dengan kehidupan sehari-hari siswa berpengaruh pada pemahaman siswa terhadap konsep materi peranan globalisasi. Dibuktikan dengan hasil kerja kelompok dibawah ini:

Tabel. 14

Hasil Kerja Diskusi Kelompok Kelas IV

SDN 1 Kapongan

\begin{tabular}{|c|c|c|c|c|c|}
\hline Siklus I & 80 & 86 & 66 & 73 & 60 \\
\hline Siklus II & 93 & 93 & 73 & 86 & 66 \\
\hline
\end{tabular}

Terlihat dalam tabel. 14 bahwa nilai kelompok siswa pada siklus I yang sudah mendapat nilai mencapai KKM terdapat tiga kelompok selebihnya masih di bawah KKM. Adapun pada siklus II nilai kelompok siswa yang memperoleh nilai di atas KKM terdapat empat kelompok, berarti adanya peningkatan dalam nilai kelompok siswa.

Tabel. 15

Penilaian Diskusi Kelompok Pada Kelas IV SDN 1 KAPONGAN

Siklus I

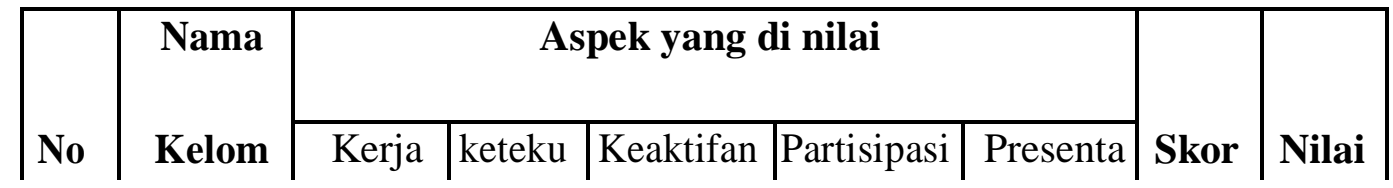

87 | Jurnal CONSILIUM (Education and Counseling Journal) 


\begin{tabular}{|l|c|c|c|c|c|c|c|c|} 
& pok & sama & An & bertanya & diskusi & $\begin{array}{l}\text { si } \\
\text { hasil } \\
\text { kerja }\end{array}$ & & \\
\hline 1 & I & 3 & 3 & 2 & 2 & 2 & 12 & 80 \\
\hline 2 & II & 3 & 3 & 2 & 3 & 2 & 13 & 86 \\
\hline 3 & III & 2 & 2 & 2 & 2 & 2 & 10 & 66 \\
\hline 4 & IV & 3 & 2 & 2 & 2 & 2 & 11 & 73 \\
\hline 5 & V & 2 & 2 & 2 & 2 & 1 & 9 & 60 \\
\hline \multicolumn{2}{|c|}{ Jumlah } & $\mathbf{1 3}$ & $\mathbf{1 2}$ & $\mathbf{1 0}$ & $\mathbf{1 1}$ & $\mathbf{9}$ & $\mathbf{5 5}$ & $\mathbf{3 6 5}$ \\
\hline \multicolumn{2}{|c|}{ Rata-rata } & $\mathbf{2 . 6}$ & $\mathbf{2 . 4}$ & $\mathbf{2 . 0}$ & $\mathbf{2 . 2}$ & $\mathbf{1 . 8}$ & $\mathbf{1 1}$ & $\mathbf{7 3}$ \\
\hline
\end{tabular}

Tabel. 16

Penilaian Diskusi Kelompok Pada Kelas IVSDN 1 Kapongan

Siklus II

\begin{tabular}{|c|c|c|c|c|c|c|c|c|}
\hline \multirow[b]{2}{*}{ No } & \multirow{2}{*}{$\begin{array}{c}\text { Nama } \\
\text { Kelom } \\
\text { pok }\end{array}$} & \multicolumn{5}{|c|}{ Aspek yang di nilai } & \multirow[b]{2}{*}{ Skor } & \multirow[b]{2}{*}{ Nilai } \\
\hline & & $\begin{array}{l}\text { Kerj } \\
\text { a } \\
\text { sama }\end{array}$ & $\begin{array}{c}\text { Kete } \\
\mathrm{k} \\
\text { unan }\end{array}$ & $\begin{array}{c}\text { Keaktifa } \\
\mathrm{n} \\
\text { bertanya }\end{array}$ & $\begin{array}{c}\text { Partisipasi } \\
\text { diskusi }\end{array}$ & $\begin{array}{l}\text { Presenta } \\
\text { si } \\
\text { hasil } \\
\text { kerja }\end{array}$ & & \\
\hline 1 & $\mathrm{I}$ & 3 & 3 & 3 & 3 & 2 & 14 & 93 \\
\hline 2 & II & 3 & 3 & 2 & 3 & 3 & 14 & 93 \\
\hline 3 & III & 3 & 2 & 2 & 2 & 2 & 11 & 73 \\
\hline 4 & IV & 3 & 3 & 2 & 3 & 2 & 13 & 86 \\
\hline 5 & V & 2 & 2 & 2 & 2 & 2 & 10 & 66 \\
\hline & lah & 14 & 13 & 11 & 13 & 11 & 62 & 411 \\
\hline
\end{tabular}




\begin{tabular}{|c|l|l|l|l|l|l|l|} 
& & & & & & & \\
\hline $\begin{array}{c}\text { Rata-rata } \\
\text { |hitung }\end{array}$ & 2.8 & 2.6 & 2.2 & 2.6 & 2.2 & $11.4 \mid$ & $82.2 \mid$ \\
\hline
\end{tabular}

\section{Kesimpulan dan Saran}

\section{a. Kesimpulan}

Berdasarkan hasil penelitian dan analisis data yang telah dilakukan, dapat disimpulkan bahwa terdapat peningkatan hasil belajar PKn dalam materi peranan globalisasi melalui pendekatan Contekstual Teaching Learning (CTL) di kelas IV SDN 1 Kapongan Kecamatan Kapongan Kabupaen Situbondo tahun pelajaran 2013/2014, terlihat pada siklus I hasil belajar pembelajaran PKn siswa Pada siklus I rata-rata nilai sebesar 69,75, sedangkan pada siklus II rata-rata nilai sebesar 77,75 mengalami peningkatan sebesar 8,0 dan dapat memenuhi KKM yaitu sebesar 70. Selanjutnya hasil pengamatan aktivitas siswa bahwa pada siklus I respons siswa atau aktivitas siswa saat pembelajaran sebesar (29.5). Selanjutnya pada siklus II respons siswa atau aktivitas siswa saat pembelajaran sebesar (33) dengan tingkat baik"kriteria".

\section{DAFTAR PUSTAKA}

Arifin, Zainal. Evaluasi Pembelajaran Prinsip, Teknik, Prosedur. Bandung: Remaja Rosdakarya, Cet. 4. 2012.

Budimansyah, Dasim., dan Karim Suryadi. PKN dan Masyarakat Multikultural. Bandung: Program Studi Pendidikan Kewarganegaraan UPI, Cet. I.2008.

Hamalik, Oemar. Dasar-Dasar Pengembangan Kurikulum. Bandung: Remaja Rosdakarya, Cet. 3. 2009.

Kusumah, Wijaya., dan Dedi Dwitagama. Mengenal Penelitian Tindakan Kelas. Jakarta: Indeks, 2009

Purwanto, Ngalim. Prinsi-Prinsip dan Teknik Evaluasi Pengajaran. Bandung: Remaja Rosdakarya, Cet. 12. 2004.

Pusat Bahasa. Kamus Besar Bahasa Indonesia Pusat Bahasa. Jakarta: Gramedia, Cet. 1.2008.

Rosalin, Elin. Gagasan Merancang Pembelajaran Kontekstual. Bandung: Karsa Mandiri Persada, 2008.

Rosyada, Dede., dkk. Buku Panduan Dosen Pendidikan Kewargaan (Civic Education) Demokrasi, Hak Asasi Manusia, dan Masyarakat Madani.

Wardhani, IGAK., dan Kuswaya Wihardit, Penelitian Tindakan Kelas. Jakarta: Universitas Terbuka, Cet. 10. 2010.

Winataputra, Udin S. Pembelajaran Pendidikan Kewarganegaraan di SD.

Jakarta: Universitas Terbuka, Cet. 14. 2014.

Okto, Dwi. Karakteristik Pendidikan Kewarganegaraan (PKN). http://id.netlog.com/oktodwi/blog/blogid=142121. (diakses hari Senin, 1April 2004, Pukul13.35WIB 
90 | Jurnal CONSILIUM (Education and Counseling Journal) 